\section{JURNAL ABDIMAS

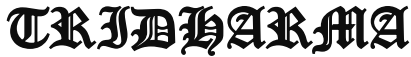 AtA}

P-ISSN 2615-6849, E-ISSN 2716-070X

Jurnal ABDIMAS Vol.3,No.1,Desember 2021,Hal(15-21)

@Prodi Manajemen Fakultas Ekonomi Universitas Pamulang

Email: abdimasjurnal.unpam@gmail.com Telp: (021) 741-2566

\title{
BERPIKIR STRATEGIS DALAM MASA PANDEMI
}

\author{
Krisnaldy, Iwan Saputro, Dennis Saputra, Dian Surya Nugroho, \\ Rizky Nur Sandi, Reni Anggraeni.
}

\section{Dosen Dan Mahasiswa Program Studi Manajemen Universitas Pamulang}

Dosen01890@unpam.ac.id, iwansaputro117@gmail.com, dennisaputraaa@gmail.com, suryadian23@gmail.com , rizkynursandi16@gmail.com, renieanggraeni22@ gmail.com

\begin{abstract}
Of course everyone will always be faced with uncertain situations, especially in the conditions of the Covid-19 pandemic. This uncertainty is increasingly seen as dynamic in a negative direction. There are many uncertain conditions faced by the community in the Covid19 pandemic situation, both political uncertainty, work continuity, children's education, and even the matter of personal safety against the increasingly widespread spread of Covid-19.

Professionals in predicting and anticipating the future, often do so with forecasting, based on previous time-to-time (time-series) data. However, it is limited to aspects that are patterned and quantitative in nature. The method used in Community Service activities at Perigi Reading Gardens is to compile a scenario with 8 dynamic steps using a powerpoint slide.
\end{abstract}

\section{Keywords: Strategic Thinking}

\begin{abstract}
Abstrak
Tentu semua orang akan selalu dihadapkan pada situasi yang tidak pasti, terutama dalam kondisi pandemi Covid-19. Ketidakpastian ini semakin terlihat dinamis kearah yang negatif. Banyak kondisi ketidakpastian yang dihadapi masyarakat dalam situasi pandemi Covid-19, baik ketidakpastian politik, keberlanjutan kerja, pendidikan anak, bahkan soal keselamatan diri terhadap penyebaran Covid-19 yang semakin luas.

Para profesional dalam memperkirakan dan mengantisipasi masa mendatang, sering melakukannya dengan prakiraan (forecasting), berdasarkan data waktu-ke-waktu (timeseries) sebelumnya. Namun itu terbatas pada aspek-aspek yang kejadianya berpola dan bersifat kuantitatif.. Metode yang digunakan dalam kegiatan Pengabdian Kepada Masyarakat di Taman Bacaan Perigi adalah menyusun skenario dengan 8 langkah yang dinamis dengan menggunakan slide powerpoint.
\end{abstract}

\section{Kata Kunci: Mengalokasikan Dana}

\section{A. PENDAHULUAN}

Tidak ada yang tahu tentang masa depan, namun masa depan harus direncanakan karena seringkali dapat mengejutkan kita. Untuk menghadapi persiapan kejutan masa depan, skenario masa depan sering dikembangkan untuk merespon dan mengantisipasi kebutuhan akan masa depan. Skenario masa depan juga digunakan dalam pengembangan kebijakan publik sebagai alat untuk mengembangkan strategi lembaga atau organisasi.

Dalam situasi tidak menentu seperti pandemi Covid-19 yang dialami seluruh dunia sekarang, tentu berdampak pada sektor politik, pendidikan, keuangan, dan lain-lain. Kita tentu harus memikirkan perubahan atau tantangan apa yang akan terjadi di masa yang akan datang. Para profesional dalam memperkirakan dan 


\section{JURNAL ABDIMAS

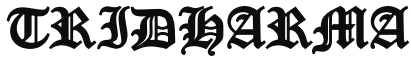 AtA}

P-ISSN 2615-6849, E-ISSN 2716-070X

Jurnal ABDIMAS Vol.3,No.1,Desember 2021,Hal(15-21)

@Prodi Manajemen Fakultas Ekonomi Universitas Pamulang

Email: abdimasjurnal.unpam@ gmail.com Telp: (021) 741-2566 mengantisipasi masa mendatang sering melakukan perkiraan atau forecasting, berdasarkan data waktu ke waktu atau time series sebelumnya. Namun itu bersifat terbatas pada aspek-aspek yang kejadiannya berpola dan bersifat kuantitatif. Berpikir strategis bisa digunakan untuk membuat sebuah skenario tentang bagaimana perubahan dan tantangan di masa depan yang berguna untuk menghindari kemungkinan kerugian dan dapat memprediksi langkah apa yang tepat untuk melalui pandemi ini.

Kemampuan menyusun skenario dapat didapatkan dengan latihan terus menerus untuk mengasah insting kita atau bisa juga dengan berdiskusi dengan rekan kerja. Terntu kita juga harus bisa menerima masukan dari rekan kerja untuk menentukan sebuah skenario yang tepat. Kemampuan berpikir strategis merupakan kemampuan untuk mempersiapkan strategi dan ide, yang akan membantu mengatasi perubahan dan tantangan yang mungkin dihadapi di masa depan. Dapat dikatakan bahwa memiliki kemampuan ini dapat mendukung karir dan pekerjaan untuk sukses.

Berpikir adalah proses dinamis, dimana individu bertindak aktif dalam menghadapi hal-hal yang bersifat abstrak. Pada proses berpikir individu membuat hubungan antara obyek yang menjadi pokok permasalahan dengan bagian-bagian pengetahuan yang sudah dimilikinya. Bagian dari pengetahuan adalah segala sesuatu yang sudah diperolehnya dalam ujud pengertian-pengertian. Adapun pengertian strategis adalah suatu hal yang mempunyai dampak atau pengaruh yang menguntungkan terhadap suatu tujuan tertentu secara jangka panjang. (Milkovich:1994). Istilah strategis sering digunakan di masyarakat untuk menyatakan suatu tempat yang lokasinya bagus atau baik. Istilah strategis juga berarti segala sesuatu yang berhubungan atau berdasarkan strategi-strategi yang telah ditentukan untuk mencapai tujuan atau target. Sesuatu dikatan strategis ketika ia dibuat atau dilaksanakan berdasarkan strategi yang dianggap paling tepat untuk mencapai tujuan. Misalnya dalam istilah perencanaan strategis, langkah strategis manajemen strategis, berpikir strategis, dan sebagainya.

Salah satu inti dari pola pikir sistem adalah berpikir strategis. Apakah yang dimaksud dengan ini? Menurut Peter Senge (1994), berpikir secara strategis berangkat dari refleksi atas inti utama yang terdapat dalam suatu persoalan yang ditangani dan tantangan-tantangan utama yang dihadapi. Dengan demikian, berpikir secara strategis lebih berupa proses untuk memahami dua hal pokok yang saling terkait: yaitu fokus dan kesadaran atas waktu (timing). Fokus lebih mengacu pada kemampuan kita dalam menempatkan perhatian kita. Kita senantiasa dihadapkan pada berbagai macam persoalan hidup, yang datang silih berganti dari waktu ke waktu.

Keadaran waktu (timing) mengacu pada pemahaman akan dinamika perubahan yang sangat erat kaitannya dengan panjangpendeknya waktu yang dibutuhkan untuk suatu perubahan. Ada kalanya suatu perubahan tertentu membutuhkan jangka waktu yang panjang; dengan demikian mustahil bila hendak dicapai dalam waktu yang singkat. Jenis perubahanyang lain bisa saja hanya membutuhkan waktu yang pendek, namun juga harus diasari pula bahwa dampak dari perubahan berdurasi pendek macam ini pun cenderung tidak berlangsung lam pul. Ada pula jenis-jenis perubahan yang bisa dicapai dsecar langsung, dan ada yang justru merupakan dampak samping dari suatu perubahan di tempat lain.l Pemahaman akan beragam model dan wkatu yang dibutuhkan, serta bagaimana perubahan bisa dicapai merupakan esensi dasar dari kemampuan berpikir strategis. Kemampuan berpikir strategis pun tercermin dalam mengangkat beragam dilema yang mendasar, baik dalam kehidupan individual maupun organisasional. Dilema ini selalu menunjukkan adanya konflik atas pilihan mana yang mesti di ambil antara dua alternatif yang tampaknya sama-sama menarik. Dengan kata lain, kemampuan berpikir strategis juga mengandaikan 


\section{JURNAL ABDIMAS

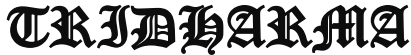

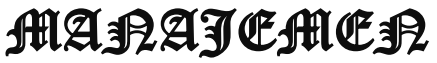

P-ISSN 2615-6849, E-ISSN 2716-070X

Jurnal ABDIMAS Vol.3,No.1,Desember 2021,Hal(15-21)

@Prodi Manajemen Fakultas Ekonomi Universitas Pamulang

Email: abdimasjurnal.unpam@gmail.com Telp: (021) 741-2566 tumbuhnya kesadaran akan prinsip-prinsip dasar serta nilai yang kita perjuangkan.

\section{B. METODE KEGIATAN \\ PELAKSANAAN}

Metode pelaksanaan pengabdian ini dilakukan dalam beberapa kegiatan yaitu tahap pertama survei, dimana kami melakukan kunjungan ke Taman Bacaan Perigi Jl. Pahlawan No. 48 Rt. 04 Rw. 07 Keduang Kec. Sawangan Kota. Depok untuk membicarakan teknik pelaksanaan dan tanggal pelaksanaan serta memberitahu apa yang akan kami lakukan dan penyusunan bahan/materi kegiatan yang meliputi: slide powerpoint . Metode kegiatan yang digunakan kepada organisasi Taman Bacaan Perigi adalah dengan memberikan penjelasan materi teori terlebih dahulu. Pelaksanaan kegiatan dilakukan pada tanggal 08 April 2021. Peserta pada kegiatan ini adalah karyawan atau sukarelawan di Taman Bacaan Perigi.

\section{HASIL DAN PEMBAHASAN}

Hasil pelaksanaan kegiatan pengabdian pada masyarakat adalah sebagai berikut:

1. Pelaksanaan Kegiatan Pengabdian Pada Masyarakat Kegiatan ini dilakukan pada tanggal 8 April 2021 sampai dengan selesai di Taman Bacaan Perigi Jl. Pahlawan No. 48 Rt. 04 Rw. 07 Keduang Kec. Sawangan Kota. Depok Kegiatan tersebut dijabarkan sebagai berikut:

a. Acara diawali dengan sambutan-sambutan dari dosen pembimbing dan mahasiswa .

b. Kemudian dilanjutkan dengan penyampaian materi pembelajaran yang di jabarkan oleh para mahasiswa kepada karyawan dan sukarelawan taman baca perigi

c. Para peserta diberikan sebuah dorongan dari para mahasiswa yang memberikan materi pembelajaran untuk kreatif dan inovatif supaya termotivasi,

d. Setelah sesi selsai pemberian materi dan pembelajaran selanjutnya para peserta di berikan Cara bagaimana menyusun skenario sesuai dengan 8 langkah dinamis

1) Hasil Kegiatan Pengabdian Kepada Masyarakat

Hasil Kegiatan Pengabdian Pada Masyarakat antara lain adalah sebagai berikut:

a). Pada sesi pemberian materi pembelajaran Dimna pemahaman para peserta belum mengetahui apa itu menyusun skenario, mereka belum pernah melakukan penyusunan skenario. Sehingga penjelasan dalam sesi pemberian materi pembelajaran ini memberikan pengetahuan baru kepada mereka.

b) Sesi pemberian materi pembelajaran sangat kondusif, para peserta dengan antusias mengikuti sesi pemberian materi pembelajaran ini, para peserta memperhatikan dengan seksama.

c) Pada sesi sharing para peserta di berikan kesempatan untuk berbicara mengenai skenario apa yang akan dilakukan dalam menghadapi pandemi Covid19 ini

\section{KESIMPULAN DAN SARAN}

\section{Kesimpulan}

Kegiatan Pengabdian Kepada Masyarakat (PKM) dengan judul :

"Berpikir Strategis Dalam Masa Pandemi Untuk Organisasi” secara umum berjalan dengan lancar dan tertib. Masyarakat antusias dalam menyimak penjelasan materi teori dan 


\section{JURNAL ABDIMAS

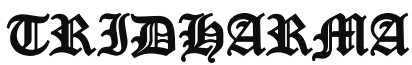

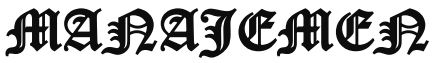

P-ISSN 2615-6849, E-ISSN 2716-070X

Jurnal ABDIMAS Vol.3,No.1,Desember 2021,Hal(15-21)

@ Prodi Manajemen Fakultas Ekonomi Universitas Pamulang

Email: abdimasjurnal.unpam@gmail.com Telp: (021) 741-2566 peragaan yang diberikan. Antusiasme masyarakat pun berlanjut saat sesi tanya jawab seputar bisnis online. Kegiatan PKM berjalan dengan efektif karena tingkat ketertarikan para peserta pada kegiatan kreatifitas, inovasi, dan tetap produktif . lain yang timbul yaitu tidak adanya media pembelajaran yang memadai untuk menjelaskan suatu konsep di luar praktikum. Hal ini akan mempersulit peserta dalam memahami konsep sehingga tak jarang masyarakat memahami di luar konsep yang sebetulnya.

\section{SARAN}

\begin{abstract}
Dengan diselenggarakan kegiatan PKM ini diharapkan dapat meningkatkan semangat para peserta agar dapat berpikir strategis untuk menyiapkan scenario apa yang bisa dibuat untuk menghadapi pandemi Covid-19 ini. Kemampuan peserta juga harus ditingkatkan dengan pelatihan-pelatihan baik dari Internal maupun Eksternal Lingkungan.
\end{abstract}

\section{E. Ucapan Terima Kasih}

Puji Syukur kami panjatkan kehadirat Allah SWT, karena telah memberikan rahmat-Nya sehingga kami dapat menyelesaikan kegiatan Pengabdian Kepada Masyarakat (PKM) dengan baik. Terimakasih juga kami ucapkan kepada Rektor Universitas Pamulang, Dekan Fakultas Ekonomi Universitas Pamulang, Ketua Program Studi Manajemen S-1 Universitas Pamulang, Ketua LPPM Universitas Pamulang, Ketua Taman Bacaan Perigi Jl. Pahlawan Rt. 04 Rw. 07 Keduang Kec. Sawangan Kab. Depok dan semua pihak yang telah berkontribusi dengan memberikan masukan sehingga laporan akhir ini dapat kami selesaikan. Kami menyadari PKM ini masih jauh dari kata sempurna dan masih banyak kekurangan oleh karena itu kami mohon saran dan kritiknya untuk pengembangan PKM selanjutnya. Dengan segala kerendahan hati kami juga berharap semoga hasil PKM ini dapat bermanfaat sebagai sumbangan pemikiran bagi masyarakat serta praktisi maupun akademisi.

\section{DOKUMEN TASI KEGIATAN}
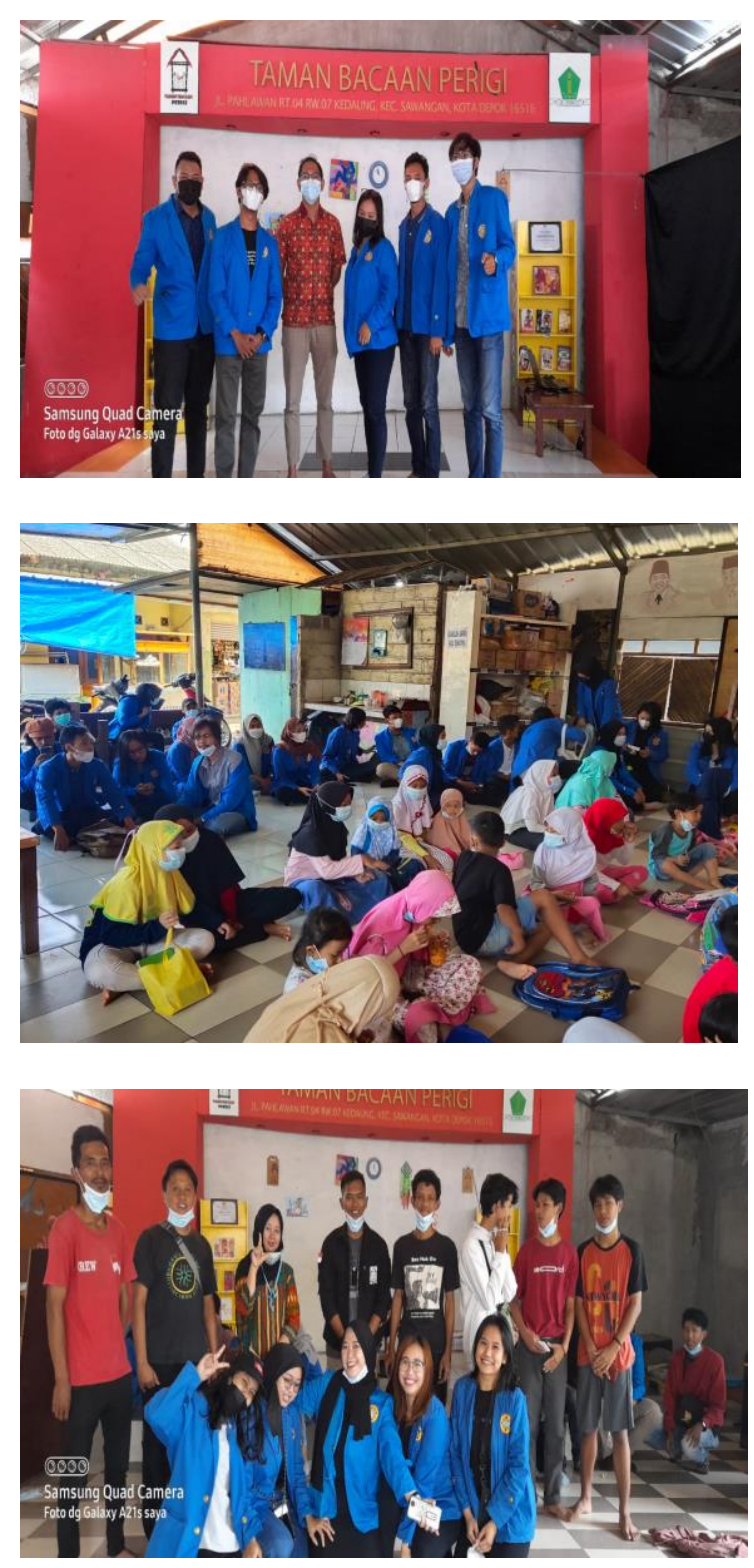

F. DAFTAR PUSTAKA

Pasaribu, V. L. D., Agrasadya, A., Shabrina, N., \& Krisnaldy, K. (2020). Menjadi Enterpreneur Muda Yang Memiliki Jiwa Leadership Untuk Menghadapi Masa Depan. Abdi Laksana: Jurnal Pengabdian Kepada Masyarakat, 1(1).

Pasaribu, V. L. D., Susanti, F., \& Hartuti, E. T. K. (2019). Memotivasi Siswa 


\section{JURNAL ABDIMAS

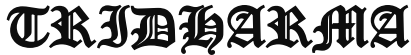 AtA}

P-ISSN 2615-6849, E-ISSN 2716-070X

Jurnal ABDIMAS Vol.3,No.1,Desember 2021,Hal(15-21)

@ Prodi Manajemen Fakultas Ekonomi Universitas Pamulang

Email: abdimasjurnal.unpam@ gmail.com Telp: (021) 741-2566 dan Siswi SMK Letris Indonesia di Dalam Menentukan Pilihan Untuk Melanjutkan Pendidikan Atau Bekerja Setelah Lulus Sekolah. Jurnal Pengabdian Dharma Laksana, 1(2), 161-172.

Pasaribu, V. L. D., Sulaiman, S., Sutiman, S., Thaharudin, T., \& Purnomo, B. Y. (2020). Pengenalan Letak Posyandu Terdekat Dikelurahan Pisangan Dengan Manajemen Pemasaran Revolusi 4.0 Untuk Meningkatkan Pengetahuan Masyarakat Letak Dan Fungsi Posyandu Terdekat Pada Kelurahan Pisangan. Dedikasi Pkm, 1(1), 105-110.

Pasaribu, V. L. D., Oktrima, B., Prabowo, B., Arianto, N., \& Haryoko, U. B. (2020). Progam Pendampingan Dan Penyelenggaraan Pendidikan Anak Pada Usia Dini Terhadap Prestasi Belajar Dilingkungan Rt $020 \mathrm{Rw}$ 009. Kel Giri Peni. Kec Wates. Yogyakarta. Jurnal Lokabmas Kreatif, 1(1), 71-75.

Pasaribu, V. L. D., Jannah, M., Fazar, M., Putra, S. P., Monalisa, M., \& Sofa, M. (2021). MENINGKATKAN PRODUKTIVITAS USAHA DIMASA PANDEMI PADA IBU PKK RT 004/003 KELURAHAN SAWAH BARU CIPUTAT, TANGERANG SELATAN. Abdi Laksana: Jurnal Pengabdian Kepada Masyarakat,2(2), 295301.

Pasaribu, V. L. D., Yuniati, H. L., Pranata, R., Sembayu, R., Purba, S. M., \& Nurbayani, T. T. A. (2021). MANAJEMEN KEUANGAN UNTUK MENGHADAPI DAN BERTAHAN DI ERA COVID 19. Jurnal Abdimas Tri Dharma Manajemen, 2(2), 12-18.

Pasaribu, V. L. D., Dwiyatni, A., Sabina, C., Ridwan, M., Gunawan, D. D., \& Noviani, B. C. (2021). EVALUASI PENERAPAN 3M DIMASA PANDEMIC COVID 19. Jurnal Abdimas Tri Dharma Manajemen, 2(2), 54-60.
Pasaribu, V. L. D., Syafei, A. N., Farhan, A., Aufaizah, A., Irani, C., \& Firtiayani, S. R. (2021). PENGARUH DISPLIN PROTOKOL KESEHATAN TERHADAP PENCEGAHAN PENULARAN VIRUS COVID19. Jurnal Abdimas Tri Dharma Manajemen, 2(2), 91-98.

Pasaribu, V. L. D., Septiani, F., Rahayu, S., Lismiatun, L., Arief, M., Juanda, A., ... \& Rahim, R. (2021). Forecast Analysis of Gross Regional Domestic Product based on the Linear Regression Algorithm Technique.

Priadi, A., Pasaribu, V. L. D., Virby, S., Sairin, S., \& Wardani, W. G. (2020). Penguatan Ekonomi Kreatif Berbasis Sumber Daya Desa Dikelurahan Rempoa. Abdi Laksana: Jurnal Pengabdian Kepada Masyarakat, 1(3), 356-35

Pasaribu, V. L. D., Priadi, A., Anismadiyah, V., Rahayu, S., \& Maduningtias, L. (2021). PENYULUHAN KREATIF DAN INOVATIF MENINGKATKAN MUTU PRODUKSI UMKM DI DESA BELEGA KABUPATEN GIANYAR. Pro Bono Jurnal Pengabdian Kepada Masyarakat, 1(02).

Pasaribu, V. L. D. (2021). PELATIHAN BERBASIS ONLINE DI ERA COVID-19. Jurnal Abdimas Tri Dharma Manajemen, 2(3), 26-32.

Pasaribu, V. L. D., \& Setyowati, R. (2021). ADAPTASI KEHIDUPAN NEW NORMAL PADA MASA PANDEMI COVID-19 DIYAYASAN PONDOK PESANTREN DAN PANTI ASUHAN NURUL IKHSAN KECAMATAN SETU, KOTA TANGERANG SELATAN. Jurnal Lokabmas Kreatif: Loyalitas 


\section{JURNAL ABDIMAS

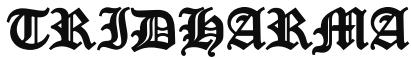

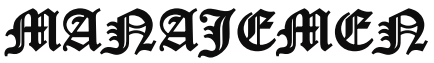

Kreatifitas Abdi Masyarakat

Kreatif, 2(2), 82-88.

https://www.ekrut.com/media/berpikir-

strategis

https://www.jojonomic.com/blog/berpikir-

$\underline{\text { strategis/ }}$

staffnew.uny.ac.id

definisimenurutparaahli.com/pengertian-

strategi/

https://www.kompasiana.com/mbudiraharjo

154ff0372a33311842850fac0/berpikir-

strategis-apa-itu 